\title{
The Effectiveness of Ozone-chlorine Treatment for Reducing Chloramine Concentration Compared to Chlorine Treatment in Swimming Pools and Whirlpools
}

\author{
Derrick J. Mah ${ }^{1}$, Helen Heacock ${ }^{2}$ \\ 1 Lead Author, B. Tech Student, School of Health Sciences, British Columbia Institute of Technology, 3700 \\ Willingdon Ave, Burnaby, BC V5G 3H2 \\ 2 Supervisor, School of Health Sciences, British Columbia Institute of Technology, 3700 Willingdon Ave, Burnaby, BC \\ V5G $3 \mathrm{H} 2$
}

\begin{abstract}
Objectives: Chloramines are by-products of chlorine disinfected swimming pools and are hazardous to people if chloramines evaporate into the air. There is evidence that chloramines cause upper respiratory tract and eye irritation. It was suspected that ozone treatment in addition to chlorine disinfection will reduce chloramine levels in the pool. The following study compared chloramine concentration in a strictly chlorine disinfected swimming pool and whirlpool (C.G. Brown) in Burnaby, BC with an ozonechlorine disinfected swimming pool and whirlpool (Killarney) in Vancouver, BC. The study also compared each pool and whirlpool to the $1.0 \mathrm{mg} / \mathrm{L}$ combined chlorine concentration limit in the B.C. Pool Regulation.

Methods: Chloramine concentrations were determined by using a Hach Pocket Colorimeter 2 Analysis System which used a DPD method of analysis. Chloramine was determined by subtracting total chlorine by the free chlorine. Thirty pool water samples were analyzed based on two samples per pool per day for fifteen days. A two sample t-test was used to compare the ozone-chlorine treated pools with the chlorine only treated pools using the Mann-Whitney $\mathrm{U}$ test. A z-test was used to compare all types of swimming pools and whirlpools to the $1.0 \mathrm{mg} / \mathrm{L}$ limit.

Results: The chloramine concentration in both the ozone-chlorine disinfected swimming pool and whirlpool was not statistically significantly lower than in the chlorine disinfected swimming pool $(\mathrm{p}=0.263597)$ and whirlpool ( $\mathrm{p}=0.523672)$. Both types of swimming pools were found to be statistically significantly greater than the $1.0 \mathrm{mg} / \mathrm{L}$ chloramine limit $(\mathrm{p}=0.000023$ in the chlorine pool and $\mathrm{p}=0.00001$ for the ozone-chlorine pool). Similarly, both types of whirlpools were determined to be statistically significantly greater than the 1.0 $\mathrm{mg} / \mathrm{L}$ chloramine limit ( $\mathrm{p}=0.000001$ for the chlorine pool and $\mathrm{p}=0.000001$ for the ozone-chlorine pool).

Conclusion: It was determined that there was no difference between ozone chlorine treated pools and chlorine only treated pools. Environmental Health Officers can suggest other forms of secondary treatment instead of ozone since there is no significant difference compared to chlorine only treated pools in reducing chloramine concentrations. This information is also beneficial for pool operators because they can increase their flow rates for pools that use ozonation or strictly chlorination relative to what they were originally designed for.
\end{abstract}

Key words: Chloramine; chlorine disinfection; ozone-chlorine disinfection; swimming pools; whirlpool

\section{Introduction}

Many people of all ages in Canada use swimming pools. People who swim do so as a recreational activity for health benefits (Lee et al., 2010). In Burnaby, there are 4 major public pools and in Vancouver there are 38 pools (indoor, outdoor, wading) (City of Burnaby, 2013; City of Vancouver, 2012). Swimming pool water can contain microbiological pathogens. Therefore, swimming pools require disinfection to protect swimmers from acquiring infections from these pathogens (Bessonneau et al., 2011; Lee et al., 2010).
The most common disinfectant used in swimming pools is chlorine (Bessonneau et al., 2011). For pool water treatment, water is taken from the pool, treated, and returned to the pool. During this process disinfectant is added, usually in the form of chlorine. The common types of chlorine disinfection used in swimming pools are chlorine gas and sodium hypochlorite (Schmalz et al., 2011). The chlorine added, independent of the type, can react with organic compounds and nitrogen compounds in the swimming pool to produce chlorination byproducts (Bessonneau et al., 2011). Some 
disinfection by-products can be hazardous (Schmalz et al., 2011). However, the production of disinfection by-products cannot be completely avoided, but they can be mitigated to a minimum (Schmalz et al., 2011).

Since disinfection by-products can be hazardous to public health, it is important to focus on pool water chemistry to prevent swimming pool related irritations (Florentin et al., 2011). A study identified two major disinfection by-products that can be produced in swimming pools: chloramines and trihalomethanes, which can both have impacts on the health of people (Judd, \& Bullock, 2003). Therefore, it is important to ensure the public, who use swimming pool facilities, are not at risk.

The most common primary method of pool water disinfection is chlorination. There are other secondary treatment methods that can disinfect pools such as Ultra Violet (UV) light and ozonation which can be used to supplement chlorine disinfection. A previous study performed by a BCIT Environmental Health student, Emily Ho (2008) found that UVchlorine disinfected pools had lower chloramine concentration compared to strictly chlorine disinfected pools. This project researched differences between ozone-chlorine disinfected pools and chlorine based disinfected pools. This project also compared the chloramine concentrations in each pool with the B.C. Pool Regulation (2010) limit of one part per million $(1.0 \mathrm{mg} / \mathrm{L})$.

\section{Literature Review}

\section{Disinfection Importance}

It is important for pools to be properly disinfected in order to destroy pathogens. Pools use chlorine because it not only oxidizes organic compounds and destroys pathogens, but it also leaves a stable residual in pool water to disinfect. Swimming pools can be a place for swimmers to transfer pathogens to another swimmer. Chemical disinfectants are used to prevent pools from containing pathogens. Disinfectants for swimming pools can be chlorine based such as sodium hypochlorite, calcium hypochlorite, chlorine gas, chlorine dioxide and chlorinated isocyanurate. But, the downside is that these chloride disinfectants can react with inorganic and organic contaminants in the pool to produce hazardous compounds, called disinfection by-products. (Florentin et al., 2011).

\section{Disinfection By-Products}

Disinfection by-products are produced when chlorine disinfectant reacts with inorganic or organic nitrogen compounds. These nitrogen compounds can enter into the pool from humans as dirt, urine, feces, sweat, hair, lotion and saliva (Cornelia Kaydos-Daniels et al., 2008; Bessonneau et al., 2011; Florentin et al., 2011). Table 1 shows how nitrogen compounds can get into the swimming pool. Each of these compounds could react with chlorine disinfectant to produce disinfection by-products (Florentin et al., 2011). But the greatest contaminant added by swimmers is urea.

In another study, it has been reported that one swimmer in the water for one hour could introduce the following contaminants into the pool: $0.15 \mathrm{~g}-0.20 \mathrm{~g}$ of ammonia (nitrogen), $1.0 \mathrm{~g}-1.6 \mathrm{~g}$ of urea and $0.55 \mathrm{~g}-1.0 \mathrm{~g}$ of total organic carbon. In addition, a swimmer in the pool for 2 hours can add between 20 - $80 \mathrm{~mL}$ of urine and $0.1-1 \mathrm{~L}$ of sweat, where both materials consist of nitrogen compounds (Florentin et al., 2011).

Overall, there are many types of human organic and inorganic nitrogen compounds that can enter into the pool. These compounds, mainly urea and creatinine (Li, \& Blatchley, 2007), can react with chlorine to produce disinfection-by-products such as chloramine.

\section{Chloramines \\ Description}

There are three types of chloramines: monochloramine, dichloramine and trichloramine. They all result from the reaction of free chlorine with dissolved organic nitrogen such as creatinine, urea and amino acids. The general reaction scheme of the production of chloramines is shown below (National Swimming Pool Foundation, 2012):

$\mathrm{HOCl}+\mathrm{R}-\mathrm{NH}_{2} \rightarrow \mathrm{R}-\mathrm{NHCl}+\mathrm{H}_{2} \mathrm{O}$

where $\mathrm{HOCl}$ is hypochlorous acid, $\mathrm{R}-\mathrm{NH}_{2}$ is organic amine, $\mathrm{R}-\mathrm{NHCl}$ is chloramine and $\mathrm{H}_{2} \mathrm{O}$ is water. The amount of chloramines produced in the water is dependent on the chlorine to nitrogen ratio (Richardson et al., 2010).

There have been reports that the concentration of chloramines in swimming pool water range from $0.1-1.5 \mathrm{mg} / \mathrm{L}$ with an air concentration between 0.17-0.43 $\mathrm{mg} / \mathrm{L}$ for trichloramines (Florentin et al., 2011). These results show that trichloramines can be found in the air which poses the greater risk.

Monochloramine, dichloramine and trichloramines that are produced are volatile. The most volatile compound of the three is trichloramine. It is slightly soluble in water as its solubility is 0.025 $\mathrm{M}$ at $25^{\circ} \mathrm{C}$ at $\mathrm{pH} 1-10$. Therefore, trichloramine concentrations above this limit will volatize into the air (Schmalz et al., 2011). Since chloramines can volatize into the air, it is not only important to have 
Table 1. Estimated human nitrogen compounds added by a swimmer.

\begin{tabular}{|c|c|c|c|c|c|}
\hline \multirow{2}{*}{$\begin{array}{l}\text { Nitrogen- } \\
\text { containing } \\
\text { compounds }\end{array}$} & \multicolumn{2}{|l|}{ Sweat } & \multicolumn{2}{|l|}{ Urine } & \multirow{2}{*}{$\begin{array}{l}\text { By swimmer } \\
\text { Estimated range of } \\
\text { input (mg) }\end{array}$} \\
\hline & $\begin{array}{l}\text { Mean content } \\
(\mathrm{mg} / \mathrm{L})\end{array}$ & $\begin{array}{l}\text { Portion of total } \\
\text { nitrogen }(\%)\end{array}$ & $\begin{array}{l}\text { Mean content } \\
(\mathrm{mg} / \mathrm{L})\end{array}$ & $\begin{array}{l}\text { Portion of total } \\
\text { nitrogen (\%) }\end{array}$ & \\
\hline Urea & 680 & 68 & 10,240 & 84 & $320-840$ \\
\hline Ammonia & 180 & 18 & 560 & 5 & $30-60$ \\
\hline Amino Acids & 45 & 5 & 280 & 2 & $15-50$ \\
\hline Creatinine & 7 & 1 & 640 & 5 & $10-25$ \\
\hline $\begin{array}{l}\text { Other } \\
\text { compounds }\end{array}$ & 80 & 8 & 500 & 4 & $20-45$ \\
\hline Total nitrogen & 992 & 100 & 12,220 & 100 & $400-1000$ \\
\hline
\end{tabular}

(Florentin et al., 2011).

adequate ventilation in an indoor swimming pool, but it is important to limit the production of chloramines. In addition, a study found that two possible ways to minimize exposure of trichloramine to swimmers is to: reduce the amount of urea in the pool or to degrade the amount of trichloramine in the pool (Schmalz et al., 2011).

\section{Regulations}

The B.C. Pool Regulation (2010), under the Public Health Act, Section 10(2)(g) states that combined chlorine must be at a concentration of 1.0 $\mathrm{mg} / \mathrm{L}$ or less. Combined chlorine is the total amount of chlorine (free chlorine and chlorine compounds) that is in the pool (National Swimming Pool Foundation, 2012). Chloramines fall into the category of combined chlorine. Therefore, pool operators must keep chloramine levels below this limit. The recommended combined chlorine levels, according to the B.C. Guidelines for swimming pool operators (Ministry of Health, 2011), is under 1.0 $\mathrm{mg} / \mathrm{L}$; this is the same as the B.C. Pool Regulation (2010).

In the pool, the greater the chlorine demand from contaminants, the greater the amount of chlorine that is required because pools must have sufficient disinfectant. The free chlorine concentration in a swimming pool must be at least $0.5 \mathrm{mg} / \mathrm{L}$ (B.C. Pool Regulation, 2010). It would be easier for operators to achieve this concentration if there were less organic contaminants in the pool for the chlorine to react with. This could be achieved by secondary treatment such as UV or ozone.

\section{Health Effects}

Chloramines are hazardous to public health. As discussed above, once chloramines accumulate to great enough levels in the water, they volatize into the air. The health effects associated with exposure to chloramines include contact dermatitis, exacerbation of pre-existing respiratory symptoms, respiratory distress, and mucous membrane irritation
(Cornelia Kaydos-Daniels et al., 2008; Florentin et al., 2011). People who are exposed to chloramines in the air can show symptoms such as throat irritation, difficulty breathing, cough, rash, and eye irritation. The median duration of symptoms was found to be 3.5 days (Cornelia Kaydos-Daniels et al., 2008). In other studies, there has been a reported relationship between people who attend chlorinated pools and an increase in their development of respiratory complaints, asthma, and allergic symptoms such as rhinitis, conjunctivitis and laryngitis (Florentin et al., 2011; Schmalz et al., 2011). Based on these symptoms and health effects, chloramines are hazardous to humans and must be maintained to low levels.

As a result of the health effects associated with chloramines, it is vital to reduce human exposure to these chemicals. One method to reduce contaminants in the pool is ozonation.

\section{Secondary/Additional Treatment \\ Ozone}

Ozone, a gaseous molecule, is used as secondary treatment in swimming pools. It is reported that ozone is a high potential oxidant and is also an effective disinfectant to kill pathogens (Lee et al., 2010; Jo et al, 2005). Since ozone is a powerful preoxidant, the amount of disinfection by-products can be reduced (Kleiser, \& Frimmel, 2000).

Ozone itself is hazardous and is not safe for humans. Ozone is denser than air. Since ozone has a low solubility, swimmers are at risk as ozone could accumulate just above the water surface. However, the risk is minor because ozone should mostly be consumed before entering the pool and there should be a deozonator to destroy remaining ozone before this water is chlorinated (National Swimming Pool Foundation, 2012).

\section{Benefits of Ozone}

Ozone is both an oxidizing agent and disinfectant, with some researchers believing that 
ozone is the most powerful oxidizing and disinfecting agent for pool water treatment. As an oxidizer, ozone can oxidize chloramines directly into nitrate and chloride (World Health Organization, 2006). As a result, combined chlorine levels in pools can be reduced. Also, ozone can oxidize organic compounds and is effective in killing viruses, bacteria and parasites such as giardia and cryptosporidium which are both chlorine resistant (National Swimming Pool Foundation, 2012). Ozone first acts as a chemical oxidant, then secondly as a disinfectant (Rice, 1995). Overall, ozone could both reduce the concentration of chloramines and reduce the number of pathogens in a swimming pool.

Since ozone is not stable in water, it is followed sequentially by chlorine disinfection. It does not produce a residual in the water (Lee et al., 2010); therefore it must be used in combination with chlorine or another type of residual disinfectant (Ministry of Health, 2011). As a result, less chlorine disinfectant is used leading to less organic disinfection by-products (Lee et al., 2010). However, there is conflicting evidence that ozone is not an effective oxidant for the major organic contaminants added by swimmers.

\section{Counterpoints of Ozone}

If ozone is not properly controlled, it can react with free chlorine in the pool resulting in less chlorine available for disinfection (Hua, \& Reckhow, 2013). Also, since ozone does not have a residual, it is not a good disinfectant for algae (Wojtowicz, 2001).

In addition, it has been reported that human contaminants of urea and creatinine are better oxidized by chlorine than ozone (Wojtowicz, 2001). Organic compounds that do not have an electron rich functional group do not get efficiently oxidized by ozone (Hübner et al., 2013). It has also been suggested that ozone slowly oxidizes monochloramine (Rice, 1995):

$\mathrm{NH}_{2} \mathrm{Cl}+3 \mathrm{O}_{3} \rightarrow 3 \mathrm{O}_{2}+2 \mathrm{H}^{+}+\mathrm{NO}_{3}^{-}+\mathrm{Cl}^{-}$

As described earlier in Table 1 , urea was a major contaminant added by swimmers. However, studies have shown that ozonation degrades urea slowly and is not very efficient (Schmalz et al, 2011). Reports have shown that ozone reacts slowly with urea, monochloramine, creatinine and ammonia, common contaminants in bathers. Chlorine is a better oxidizer for these compounds (Wojtowicz, 2001). Ozone would only be effective at oxidizing certain chloramines but possibly not the precursors that produce these compounds. This could allow chloramines to build up faster than could be eliminated since there could be less chlorine added in pools that are ozone-chlorine treated.

\section{Research Question}

The purpose of this study was to determine if ozonechlorine disinfection of indoor swimming pools and whirlpools result in lower chloramine concentration than chlorinated disinfection in indoor swimming pools and whirlpools, respectively.

The hypothesis was that there will be a significant difference whereby ozone-chlorine treated pools/whirlpools will have less chloramine concentration compared to chlorine treated pools/whirlpools and that all pools will be under the $1.0 \mathrm{mg} / \mathrm{L}$ chloramine limit.

\section{Role of the Environmental Health Officer}

The duty of the environmental health officer (EHO) is to protect the public from health hazards which can be in the form of chemical (spills, $\mathrm{pH}$, chloramine), physical (entrapment, drowning, accidents) and biological (communicable diseases) hazards (MacLeod, 2013a). Section 23 under the Public Health Act (2008) provides EHOs with the power to inspect and enforce the Act and the regulations under the Act including the B.C. Pool Regulation (2010). To protect the public from hazards in the public pool environment, the EHO must protect the health and safety of the public through routine inspections, facility approval, regulatory enforcement and investigation of complaints and disease outbreaks involving public swimming pools.

As described previously, Section 10(2)(g) under the B.C. Pool Regulation restricts public swimming pools to a chloramine limit of one part per million in the water. Relating to this project, EHOs ensure the chloramine concentration is not high, which can be hazardous, and to enforce the limit by sampling the pool water to measure the chloramine concentration and taking appropriate action, if necessary.

\section{Methods and Materials}

To compare the concentration of chloramines in each type of pool disinfectant, two different pools were sampled. The ozone-chlorine disinfected pool was the Killarney pool in Vancouver, BC. This pool had a swimming pool volume of 180,000 US gallons and a whirlpool volume of 6,000 US gallons. The bather load was approximately 1,000 patrons per day (K. Hillman, personal communication, January 20, 2014). 
The chlorine disinfected pool was the C.G. Brown pool in Burnaby, BC, which had a swimming pool volume of approximately 167,000 US gallons and whirlpool volume 3,330 US gallons. The bather load was approximately 525 patrons per day (B. Gillman, personal communication, January 7, 2014).

In the two different types of disinfected swimming pools, chloramine (also known as combined chlorine) was determined by subtracting the concentration of free chlorine from the concentration of total chlorine in the pool (Bessonneau, 2011; Cornelia Kaydos-Daniels, 2008). To determine this the Hach Pocket Colorimeter 2 Analysis System (Catalog \# 59571-88) was used in addition to DPD Free Chlorine powder pillows (14070-99), DPD Total Chlorine powder pillows (14064-99), and DPD -Chlorine HR Spec Check Secondary Standards Kit (28933-00).

Samples were taken in January 2014 at each pool location. Each public swimming pool and whirlpool were sampled two times per day for 15 total days, for a total for 30 samples per pool location. Sampling occurred in various times of the day in different sites around the pool, 18 inches deep in the pool away from any return outlets.

\section{Statistical Analysis \& Results}

\section{Description of Type of Data}

The type of data was numerical data since concentration was measured. The concentration of chlorine, in the two different pools, was determined to a precision of one decimal point. To calculate the concentration of chloramines, the total chlorine measurement was subtracted by the free chlorine measurement, as discussed in the standard methods. The chloramine concentration was the data inputted into the statistics program maintaining the one decimal point. Since the concentration involves decimals, it was continuous numeric data because the "measurement is on a continuum" (Heacock, \& Sidhu, 2013a).

Table 2. Descriptive statistics for the chloramines concentrations in chlorine and ozone-chorine disinfected swimming pools and whirlpools.

\begin{tabular}{|l|l|l|l|l|}
\hline Statistic & $\begin{array}{l}\text { Chlorine } \\
\text { Disinfectant Pool } \\
\text { (mg/L) }\end{array}$ & $\begin{array}{l}\text { Ozone-Chlorine } \\
\text { Disinfectant Pool } \\
\text { (mg/L) }\end{array}$ & $\begin{array}{l}\text { Chlorine } \\
\text { Disinfectant } \\
\text { Whirlpool (mg/L) }\end{array}$ & $\begin{array}{l}\text { Ozone-Chlorine } \\
\text { Disinfectant } \\
\text { Whirlpool (mg/L) }\end{array}$ \\
\hline Mean & 1.47 & 1.31 & 2.02 & 1.89 \\
\hline Mode & 1.1 & 1.4 & 1.6 & 1.9 \\
\hline Median & 1.3 & 1.3 & 1.75 & 1.85 \\
\hline Range & 3.0 & 1.7 & 2.7 & 1.7 \\
\hline Standard Deviation & 0.62 & 0.33 & 0.68 & 0.40 \\
\hline
\end{tabular}

\section{Descriptive Statistics}

Descriptive statistics, Table 2, for the data was calculated using Microsoft Excel (2007). Based on Table 2, the mean, range and standard deviation from the ozone-chlorine disinfectant pool are lower than the chlorine disinfected pool. With regards to the whirlpools, the ozone-chlorine disinfected whirlpool had a lower mean, range and standard deviation but a larger mode and median compared to the chlorine disinfected whirlpool.

\section{Inferential Statistics}

There were two independent groups that were tested: chloramine concentration in chlorine disinfected pool and chloramine concentration in ozone-chlorine disinfected pool. The other two independent groups there were tested were: chloramine concentration in the chlorine disinfected whirlpool and chloramine concentration in the ozone-chlorine disinfected whirlpool. Based on these two independent groups, a t-test was used using NCSS 9 (Heacock, \& Sidhu, 2013b; Hintze, 2013). A one tail t-test was used because it was suspected that the ozone-chlorine disinfected pool would have less chloramine levels than the chlorine disinfected pool (MacLeod, 2013b).

Furthermore, a z-test was applied to each independent variable: the two different disinfected swimming pools and the two different whirlpools. The chloramine concentrations of each independent variable were compared to a value of $1.0 \mathrm{mg} / \mathrm{L}$, which is the limit in the B.C. Pool Regulation (2010). The chloramine concentrations were expected to be below this limit.

\section{Statistical Analysis}

Interpretation of Results

The following are the results for the comparison of the chlorine pool with the ozone-chlorine pool. 
Based on the results in the Tests of Assumptions, the results from the non-parametric Mann-Whitney U or Wilcoxon Rank Sum Test were used (Heacock, \& Sidhu, 2013b).

Under the Mann-Whitney U or Wilcoxon Rank Sum Test, the one tail t-test Diff $>0$ alternative hypothesis was examined because it was expected that the chloramine concentration in the chlorine disinfected pool was to be greater than the chloramine concentration in the ozone-chlorine disinfected pool (MacLeod, 2013b). Please refer to Table 3 below for the hypothesis.

Since $p=0.263597$, the null hypothesis was not rejected and it was concluded that there was not a statistically significant difference between chloramine concentration in chlorine disinfected pools and chloramine concentration in ozone-chlorine disinfected pools. Chloramine concentration in chlorine disinfected pools was similar to the chloramine concentration in ozone-chlorine disinfected pools.

\section{Alpha and Beta Errors}

As stated, based on the Mann-Whitney U or Wilcoxon Rank Sum Test, the p value was 0.263597. Therefore, the $\mathrm{p}$ value was not associated with $\alpha-$ error.

The power, using the Equal-Variance $\mathrm{T}$ Test, is 0.32114. A low power, less than 0.80, suggested that there was a low probability that there was a statistically significant difference in chloramine concentration between the chlorine disinfected pool and the ozone-chlorine disinfected pool (Heacock, \& Sidhu, 2013b). With a ß value of 0.679 , there is possible $\beta$ - error and a larger sample size is needed to reduce the chance of $\beta$ - error

Table 3. Summary of Statistics and Results of All Hypotheses

\begin{tabular}{|c|c|c|c|}
\hline $\mathbf{H}_{0}$ & p-value & Conclusion & Power \\
\hline $\begin{array}{l}\text { The chloramine concentration in the chlorine } \\
\text { disinfected swimming pool will be less than the } \\
\text { chloramine concentration in the ozone-chlorine } \\
\text { disinfected swimming pool }\end{array}$ & $\begin{array}{l}0.263597 \\
\text { Non-parametric Mann- } \\
\text { Whitney U }\end{array}$ & Cannot reject $\mathrm{H}_{0}$ & 0.32114 \\
\hline $\begin{array}{l}\text { The chloramine concentration in the chlorine } \\
\text { disinfected whirlpool will be less than the } \\
\text { chloramine concentration in the ozone-chlorine } \\
\text { disinfected whirlpool }\end{array}$ & $\begin{array}{l}0.523672 \\
\text { Non-parametric Mann- } \\
\text { Whitney U }\end{array}$ & Cannot reject $\mathrm{H}_{0}$ & 0.21814 \\
\hline $\begin{array}{l}\text { The chloramine concentration in the chlorine } \\
\text { disinfected swimming pool will be less than the } \\
\text { chloramine concentration limit of } 1.0 \mathrm{mg} / \mathrm{L}\end{array}$ & $\begin{array}{l}0.000023 \\
\text { Non-parametric } \\
\text { Wilcoxon Signed Rank } \\
\text { Test }\end{array}$ & Reject $\mathrm{H}_{0}$ & 0.99149 \\
\hline $\begin{array}{l}\text { The chloramine concentration in the ozone- } \\
\text { chlorine disinfected swimming pool will be less } \\
\text { than the chloramine concentration limit of } 1.0 \\
\mathrm{mg} / \mathrm{L}\end{array}$ & $\begin{array}{l}0.00001 \\
\text { Parametric One } \\
\text { Sample T-Test }\end{array}$ & Reject $\mathrm{H}_{0}$ & 0.99962 \\
\hline $\begin{array}{l}\text { The chloramine concentration in the chlorine } \\
\text { disinfected whirlpool will be less than the } \\
\text { chloramine concentration limit of } 1.0 \mathrm{mg} / \mathrm{L}\end{array}$ & $\begin{array}{l}0.000001 \\
\text { Non-parametric } \\
\text { Wilcoxon Signed Rank } \\
\text { Test } \\
\end{array}$ & Reject $\mathrm{H}_{0}$ & 1.00000 \\
\hline $\begin{array}{l}\text { The chloramine concentration in the ozone- } \\
\text { chlorine disinfected whirlpool will be less than } \\
\text { the chloramine concentration limit of } 1.0 \mathrm{mg} / \mathrm{L}\end{array}$ & $\begin{array}{l}0.000001 \\
\text { Non-parametric } \\
\text { Wilcoxon Signed Rank } \\
\text { Test }\end{array}$ & Reject $\mathrm{H}_{0}$ & 1.00000 \\
\hline
\end{tabular}


Results of Other Hypothesis

Table 3, below, shows a summary of the other hypothesis tests comparing:

- The chlorine whirlpool and ozone-chlorine whirlpool chloramine concentration

- Each type of pool/whirlpool to a chloramine concentration limit of $1.0 \mathrm{mg} / \mathrm{L}$

In summary there was no statistically significant difference between the chlorine disinfected swimming pool and the ozone-chlorine disinfected swimming pool and $\mathrm{H}_{0}$ was not rejected. There was no statistically significant difference between the chlorine disinfected whirlpool and the ozone-chlorine disinfected whirlpool and $\mathrm{H}_{0}$ was not rejected. Chloramine concentration in ozonechlorine disinfected pools and whirlpools was less than in chlorine only disinfected pools and whirlpools. In all types of pools and whirlpools, the chloramine concentration exceeded the $1.0 \mathrm{mg} / \mathrm{L}$ limit. All of the t-tests and z-tests did not have $\alpha-$ error because the $p$ value was not between 0.01 and 0.05 . Neither did any of the tests that rejected $\mathrm{H}_{0}$ have ß-error because the power was above 0.8 .

In comparing the chloramine concentrations between swimming pools and whirlpools, the mean chloramine concentration in whirlpools was greater than swimming pools (Table 2). The reason for this is because the whirlpool volumes are much smaller than the swimming pool in addition to people sweating more in whirlpools. As a result, chloramines can build up faster in whirlpools. Even though whirlpools should have a turnover rate every 20 minutes, a swimming pool turnover rate is around 6 hours (Macleod, 2013c). A turnover rate is the amount of time that it takes for the entire volume of pool water to go through the circulation system.

\section{Discussion}

\section{Significance and Implications}

Based on the results, there is no difference in the chloramine concentration between ozone-chlorine treated pools and chlorine only treated pools. This means that using ozone as a secondary treatment to supplement chlorination does not make a difference in reducing the chloramine concentrations. This is contrary to the literature review where it was found that ozone is effective in reducing chloramine concentrations in pool waters (World Health Organization, 2006).
Furthermore, neither ozone-chlorine treatment nor chlorine only treatment were effective in reducing the chloramine concentration below the $1.0 \mathrm{mg} / \mathrm{L}$ limit under the B.C. Pool Regulation (2010). This means that the flow rates that were set for the Killarney and CG Brown swimming pools and whirlpools were not great enough to reduce the chloramine concentration. In order to reduce chloramine concentrations in the pools, the flow rates should be increased. Another option is to use UV as a secondary treatment.

As stated in the literature review, Emily Ho (2008) determined that UV-chlorine treatment reduced chloramine concentrations lower than strictly chlorine treated swimming pools. The combination of results from Emily's project and this current project could be beneficial for EHOs. When looking over pool plans with regards to secondary treatment, EHOs could suggest UV to be used instead of ozone because it has demonstrated to be more effective in reducing chloramine concentrations.

Even though there was no difference between ozone-chlorine treated pools and chlorine only treated pools, and neither was able to be under the $1.0 \mathrm{mg} / \mathrm{L}$ limit, it is not a major cause for concern. The chloramine concentration mean for the ozone-chlorine treated swimming pool was $1.3 \mathrm{mg} / \mathrm{L}$ and for the chlorine treated swimming pool was 1.5 $\mathrm{mg} / \mathrm{L}$ which was not greatly over the $1.0 \mathrm{mg} / \mathrm{L}$ limit. The chloramine concentration mean for the ozonechlorine treated whirlpool was $1.9 \mathrm{mg} / \mathrm{L}$ and for the chlorine treated whirlpool was $2.0 \mathrm{mg} / \mathrm{L}$ which is somewhat of a concern. But as long as major factors of free chlorine, $\mathrm{pH}$ and alkalinity are within the limits set in the BC Pools Regulation (2010) along with adequate air ventilation, chloramine concentrations at these pools should not pose a problem to public health. But, as an EHO, the flow rates should be increased for both types of whirlpools or to drain and refill the whirlpool water to reduce the chloramine concentrations.

Also, to measure chloramine concentrations, pool operators use a device that is not as accurate as the Hach Pocket Colorimeter 2 Analysis System, which was used for this project. Most pool operators use the colorimetric method colour matching the sample with colour standards. However, this is not as accurate or precise. These types are usually accurate to $0.5 \mathrm{mg} / \mathrm{L}$. Pool operators, using their device, would measure the results from both swimming pools as $1.0 \mathrm{mg} / \mathrm{L}$ which would be within the limit and would measure the results from both whirlpools as 1.5 or $2.0 \mathrm{mg} / \mathrm{L}$ which would appear to be above the $1.0 \mathrm{mg} / \mathrm{L}$ limit. Therefore, depending on the 
measuring device, pool operators may measure their chloramine concentration to be $1.0 \mathrm{mg} / \mathrm{L}$ when it may be $1.3 \mathrm{mg} / \mathrm{L}$. However, this is not a major difference.

The results from this study could have an effect on EHOs, pool operators and the public. With regards to EHOs, when looking over pool plans during the construction stage, EHOs could suggest the use of UV light instead of ozonation as secondary treatment. In addition, EHOs should also be aware that pools using ozone as secondary treatment to chlorine are not necessarily better than pools using only chlorine. EHOs can also educate pool operators that ozonation does not significantly reduce chloramine concentrations compared to chlorine alone.

Pool operators should be aware of the results just as EHOs, as stated above. They should be knowledgeable that ozone secondary treatment to chlorine does not significantly reduce chloramine concentrations compared to chlorine only treated pools. For both types of swimming pools, pool operators should increase their flow rate more so than originally planned in their pool design, to increase turnover rates for faster treatment; this could reduce chloramine levels.

The public is not significantly affected by the results from this project. The pools need to be within specific parameters under the B.C. Pool Regulation (2010), enforced by EHOs, for pools to be safe. Parameters such as free chlorine, chloramine (combined chlorine), $\mathrm{pH}$, and alkalinity will prevent the public from harmful effects associated with the pool. The public could choose to swim at pools that use UV as secondary treatment to chlorine instead of ozone-chlorine and chlorine only pools because there may be less risk of an outbreak or hazard, but the risk is not significantly less because all pools are routinely inspected by EHOs to ensure that they are all safe under the same requirements set by the B.C. Pool Regulation (2010).

\section{Anomalies}

Based on research by Kleiser, \& Frimmel (2000) and World Health Organization (2006), ozonation effectively oxidizes chloramines thereby reducing the chloramine concentration in swimming pools. However, the results from this current study do not support the literature. There was no difference between ozone-chlorine treatment and chlorine only treatment; in other words, ozone did not effectively reduce chlorinamine levels below that of strictly chlorine treated pools. Possible reasons why there was a difference between the results in this study and in literature is that there was a difference in pool size and bather load in the Killarney pools and CG Brown pools where Killarney had the larger pool and higher bather load. This difference in bather load could lead to differences in chloramine levels because bathers contribute to the production of chloramines. This could explain why the ozone-chlorine treated pools were not statistically different than chlorine only treated pools because the ozone-chlorine treated pools had a greater bather load, thus greater chloramine levels to reduce.

\section{Overall Contribution of the Project}

Overall, this project demonstrated that ozone as a secondary treatment to chlorine is not different than strictly chlorine in reducing chloramine concentrations in swimming pools and whirlpools. If new pools are to be designed using secondary treatment, it would be more beneficial to use UV light instead of ozonation. There appears to be a trend to use UV light as a secondary treatment instead of ozonation and these results support that ozonation is not effective in reducing chloramine concentrations.

\section{Recommendations}

1. The results of this study could be used to show that ozone as a secondary treatment does not significantly reduce chloramine concentrations in swimming pools and whirlpools compared to strictly chlorine treated pools. The literature shows that ozone is a strong oxidizing agent and should oxidize chloramines, but based on this project, chloramines were not oxidized sufficiently to reduce chloramine concentrations. Based on these results, pool operators using ozone as a secondary treatment to chlorine should increase the flow rate and turnover rate in their swimming pools and whirlpools to allow more pool water to be treated by ozone.

2. EHOs can use these results by suggesting alternative secondary treatment methods such as UV light instead of ozone because based on this project, ozone was not significantly different than chlorine only treatment.

3. It is still unknown how effective ozone is as a secondary treatment to chlorine only treatment because of the possible source of error in the difference in bather loads and pool volumes in both types of pools. Further studies can use different pools with the same bather load and pool volume. 


\section{Limitations}

Possible sources of error that could have occurred during this research were with the pools that were chosen. As stated previously, the difference in the bather load of the swimming pools and whirlpools between the two types of treatment systems could influence the amount of chloramines in the pools. This project could be explored more by comparing two pools with the same bather load and pool volume. This was not followed through to limit travel time to pools and time constraints.

Another way to reduce the difference in bather load is to sample from many different pools instead of just one ozone-chlorine treated pool and one strictly chlorine treated pool. In other words, more different ozone-chlorine treated pools and more strictly chlorine treated pools to get at least 30 samples total for each type of treatment system. This could reduce differences in bather load unless all of the ozone-chlorine pools have greater or less bather load than all of the chlorine only pools. Again, this was not performed in this project due to time constraints.

\section{Future Studies}

1. Perform the same study using ozone-chlorine pools and chlorine only pools that have the same pool volume and bather loads, or sample more pools that use ozone-chlorine treatment and chlorine only treatment pools instead of just one of each type.

2. Determine if there is a difference in chloramine concentrations at different depths and areas of the swimming pool.

3. Determine the accuracy of the 5 in 1 Aquachek test strips for free chlorine, total chlorine, total alkalinity, $\mathrm{pH}$, and total hardness. Or determine the accuracy of the 5 in 1 Aquachek test strips for measuring chloramine (combined chlorine) concentrations.

\section{Conclusion}

It was determined that there was no difference in the chloramine concentration between ozone-chlorine treated swimming pools and chlorine only treated swimming pools. Also, there was no difference between ozone-chlorine treated whirlpools and chlorine only treated whirlpools. These results are different than the expected result of ozone-chlorine treated pools having less chloramine levels compared to chlorine only treated pools.
Also, neither any of the ozone-chlorine or chlorine only treated pools were under the $1.0 \mathrm{mg} / \mathrm{L}$ limit. Since the ozone-chlorine and chlorine only treated swimming pools were near the $1.0 \mathrm{mg} / \mathrm{L}$ limit, there would not be a distinct difference that could be detected by the device pool operators use. However, the both types of whirlpools were near $2.0 \mathrm{mg} / \mathrm{L}$ and pool operators would be able to determine that it is above $1.0 \mathrm{mg} / \mathrm{L}$ using their measuring device.

\section{Acknowledgements}

There are many people who I would like to thank which made this project possible. First, I would like to thank Helen Heacock my supervisor for this project and who was the person suggesting this project. Also, special thanks to Fred Shaw for his organization and for providing the equipment for this project. I would also like to thank Bert Gillman from C.G. Brown, Karen Hillman and Adam from Killarney, and Sean Healy from the Vancouver Board of Parks \& Recreation for being extremely helpful with my questions and providing access to these pool facilities.

\section{References}

B.C. Pool Regulation 296/2010. (2010). Retrieved from http://www.bclaws.ca/EPLibraries/bclaws_n ew/document/ID/freeside/296_2010

Bessonneau, V., Derbez, M., Clément, M., \& Thomas, O. (2011). Determinants of chlorination by-products in indoor swimming pools. International journal of hygiene and environmental health, 215, 7685.

City of Burnaby. (2013). Swimming. Retrieved from http://www.burnaby.ca/Things-To-Do/BeActive-Programs/Rates-andSchedules/Swimming.html

City of Vancouver. (2012, May 30). Swimming and water activities. Retrieved from http://vancouver.ca/parks-recreationculture/swimming-and-water-activities.aspx

Cornelia Kaydos-Daniels, S., Beach, M.J., Shwe, T., Magri, J., \& Bixler, D. (2008). Health effects associated with indoor swimming pools: A suspected toxic chloramines exposure. Public health, 122, 195-200. doi:10.1016/j.puhe.2007.06.011

Florentin, A., Hautemanière, A., \& Hartemann, P. (2011). Health effects of disinfection by- 
products in chlorinated swimming pools. International journal of hygiene and environmental health, 214, 461-469. doi:10.1016/j.ijheh.2011.07.012

Heacock, H., \& Sidhu, B. (2013a). Research Methods Module 5: Descriptive statistics. Personal Collection of H. Heacock, \& B. Sidhu, British Columbia Institute of Technology, Burnaby, BC, Canada.

Heacock, H., \& Sidhu, B. (2013b). Research Methods Module 5: Inferential statistics. Personal Collection of H. Heacock, \& B. Sidhu, British Columbia Institute of Technology, Burnaby, BC, Canada.

Hintze, J. (2013). NCSS 9. NCSS, LLC. Kaysville, Utah, USA. Retrieved from www.ncss.com.

Ho, E. (2008). Concentration of chloramines in chlorinated vs UV pools. (Unpublished research project). British Columbia Institute of Technology, Burnaby, BC, Canada.

Hua, G., \& Reckhow, D.A. (2013). Effect of preozonation on the formation and speciation of DBPs. Water research, 47, 4322-4330. http://dx.doi.org/10.1016/j.watres.2013.04.0 57

Hübner, U., Keller, S., \& Jekel, M. (2013). Evaluation of the prediction of trace organic compound removal during ozonation of secondary effluents using tracer substances and second order rate kinetics. Water research, 47(17), 6467-6474. doi: 10.1016/j.watres.2013.08.025

Jo, W., Kwon, K., Dong, J., \& Chung, Y. (2005). Multi-route trihalomethane exposure in households using municipal tap water treated with chlorine or ozone-chlorine. Science of the total environment, 339, 143152. doi: 10.1016/j.scitotenv.2004.07.026

Judd, S.J., \& Bullock, G. (2003). The fate of chlorine and organic materials in swimming pools. Chemosphere, 51, 869-879. doi:10.1016/S0045-6535(03)00156-5

Kleiser, G., \& Frimmel, F.H. (2000). Removal of precursors for disinfection by-products (DBPs) - Differences between ozone- and $\mathrm{OH}$-radical-induced oxidation. The science of total environment, 256, 1-9.

Lee, J., Jun, M.J., Lee, M.H., Lee, M.H., Eom, S.W., \& Z, K.D. (2010). Production of various disinfection byproducts in indoor swimming pool waters treated with different disinfection methods. International journal of hygiene and environmental health, 213, 465-474. doi:10.1016/j.ijheh.2010.09.005
Li, J., \& Blatchley, E.R. (2007). Volatile disinfection byproduct formation resulting from chlorination of organic-nitrogen precursors in swimming pools. Environmental science \& technology, 41(19), 6732-6739.

MacLeod, M. (2013a). Pools and recreational waters. Personal Collection of Martin MacLeod, British Columbia Institute of Technology, Burnaby, BC.

MacLeod, M. (2013b). Ozone and Ozonation. Personal Collection of Martin MacLeod, British Columbia Institute of Technology, Burnaby, BC.

MacLeod, M. (2013c). The (re)circulation system. Persona Collection of Martin MacLeod, British Columbia Institute of Technology, Burnaby, BC.

Microsoft. (2007). Microsoft Excel (Version 2007). Microsoft Corporation.

Ministry of Health. (2011). B.C. Guidelines for swimming pool operators V1.0. Retrieved from

http://www.health.gov.bc.ca/protect/pdf/bcpool-operations-guidelines.pdf

National Swimming Pool Foundation. (2012). Pool \& spa operator handbook. Colorado Springs, CO: National Swimming Pool Foundation.

Public Health Act, S.B.C. 2008. (2008, c. 28). Retrieved from BC Laws website: http://www.bclaws.ca/EPLibraries/bclaws_n ew/document/ID/freeside/00_08028_01\#part 4

Rice, R.G. (1995). Chemistries of ozone for municipal pool and spa water treatment. Journal of the swimming pool and spa industry, 1(1), 25-44.

Richardson, S.D., DeMarini, D.M., Kogevinas, M., Fernandez, P., Marco, E., Lourencetti, C., Ballesté, C., Heederik, D., Meliefste, K., McKague, A.B., Marcos, R., Ront-Ribera, L., Grimalt, J.O., \& Villanueva, C.M. (2010). What's in the pool? A comprehensive identification of disinfection by-products and assessment of mutagenicity of chlorinated and brominated swimming pool water. Environmental health perspectives, 118(11), 1523-1530. doi:10.1289/ehp.1001965

Schmalz, C., Frimmel, F.H., \& Zwiener, C. (2011). Trichloramine in swimming pools Formation and mass transfer. Water research, 46, 2681-2690. doi:10.1016/j.watres.2011.02.024 
World Health Organization. (2006). Guidelines for safe recreational water environments. Volume 2: Swimming pools and similar environments. Retrieved from http://whqlibdoc.who.int/publications/2006/ 9241546808_eng.pdf

Wojtowicz, J.A. (2001). Use of ozone in the treatment of swimming pools and spas. Journal of the swimming pool and spa industry, 4(1), 41-53. 